\title{
Carbapenem Resistance among Marine Bacteria-An Emerging Threat to the Global Health Sector
}

\author{
Dewa A.P. Rasmika Dewi ${ }^{1,2}$, Torsten Thomas ${ }^{3}$, Ana Masara Ahmad Mokhtar ${ }^{4} \mathbb{D}$, Noreen Suliani Mat Nanyan ${ }^{4}$, \\ Siti Balqis Zulfigar 4 (D) and Nor Hawani Salikin $4, *$ (D)
}

1 School of Medicine, International University of Health and Welfare, Narita 286-8686, Japan; d-dewi@iuhw.ac.jp

2 Faculty of Medicine and Health Sciences, Udayana University, Bali 80232, Indonesia

3 Centre for Marine Science and Innovation, School of Biological, Earth and Environmental Sciences, The University of New South Wales, Sydney 2052, Australia; t.thomas@unsw.edu.au

4 School of Industrial Technology, Universiti Sains Malaysia, Gelugor 11800, Penang, Malaysia; anamasara@usm.my (A.M.A.M.); noreen_nanyan@usm.my (N.S.M.N.); balqiszulfigar@usm.my (S.B.Z.)

* Correspondence: norhawani@usm.my; Tel.: +60-4-653-2241

check for updates

Citation: Dewi, D.A.P.R.; Thomas, T.; Ahmad Mokhtar, A.M.; Mat Nanyan, N.S.; Zulfigar, S.B.; Salikin, N.H. Carbapenem Resistance among Marine Bacteria-An Emerging Threat to the Global Health Sector. Microorganisms 2021, 9, 2147. https://doi.org/10.3390/ microorganisms 9102147

Academic Editor: Danny Morick

Received: 14 September 2021

Accepted: 10 October 2021

Published: 14 October 2021

Publisher's Note: MDPI stays neutral with regard to jurisdictional claims in published maps and institutional affiliations.

Copyright: (c) 2021 by the authors. Licensee MDPI, Basel, Switzerland. This article is an open access article distributed under the terms and conditions of the Creative Commons Attribution (CC BY) license (https:/ / creativecommons.org/licenses/by/ $4.0 /)$.

\begin{abstract}
The emergence of antibiotic resistance among pathogenic microorganisms is a major issue for global public health, as it results in acute or chronic infections, debilitating diseases, and mortality. Of particular concern is the rapid and common spread of carbapenem resistance in healthcare settings. Carbapenems are a class of critical antibiotics reserved for treatment against multidrug-resistant microorganisms, and resistance to this antibiotic may result in limited treatment against infections. In addition to in clinical facilities, carbapenem resistance has also been identified in aquatic niches, including marine environments. Various carbapenem-resistant genes (CRGs) have been detected in different marine settings, with the majority of the genes incorporated in mobile genetic elements, i.e., transposons or plasmids, which may contribute to efficient genetic transfer. This review highlights the potential of the marine environment as a reservoir for carbapenem resistance and provides a general overview of CRG transmission among marine microbes.
\end{abstract}

Keywords: infectious diseases; safe water access; marine bacteria; carbapenem resistance

\section{Introduction}

Antibiotic resistance (AR) is a public health crisis that leads to increasingly complex and expensive treatments, longer hospital stays, and higher mortality [1]. The Centre for Disease Prevention and Control (CDC) has estimated that in the United States alone, two million people are infected by antibiotic-resistant bacteria (ARB), resulting in 23,000 fatalities every year [2]. The WHO estimates that this number will increase to approximately 10 million deaths per year by 2050 if the AR problem is not addressed [3,4]. ARB can be found in humans, animals, plants, and the environment, such as in water and soil [5], and may spread among humans, between humans and animals, from humans or animals to the environment, or vice versa [6-10]. The factors contributing to the emergence and spread of ARB include the overuse or misuse of antimicrobials; poor infection prevention and control in healthcare facilities; lack of access to clean water, sanitation, and hygiene for humans and animals; lack of knowledge and awareness; and lack of legislation enforcement [5]. Furthermore, the rapid global spread of ARB that have acquired new resistance mechanisms has, alarmingly, resulted in multi- and pan-resistant bacteria, also known as "superbugs" [5]. Consequently, only a few antibiotics are left to treat human infections caused by these multi-drug-resistant bacteria [11-13]. The WHO, therefore, suggests that prevention and containment methods are required to decrease the spread of ARB, and these include improved methods for antibiotic prescription, the regulation of antibiotics use, the development of new antimicrobial drugs and vaccines, and improved surveillance of ARB [5]. 
The most diverse ARB worldwide are those that produce beta-lactamases ( $\beta$-lactam hydrolysing enzymes). More than 1000 beta-lactamases, including newly discovered classes of genes and their mutations, have been identified [14]. The $\beta$-lactams belonging to the class of carbapenems are very efficient antibiotics that are widely used to treat severe or high-risk bacterial infections. Due to their broad spectrum of activity and efficacy against both Gram-positive and Gram-negative bacteria, carbapenems are considered a "last resort" antibiotic to treat severely ill patients or those suspected of carrying multi-resistant bacteria [15]. Alarmingly, carbapenem resistance (CR) has been reported globally [15-17], with the synthesis of carbapenemases being the most common mechanism underpinning resistance [15,17-19]. Furthermore, several cases of CR have been reported in bacteria outside the hospital setting, including rivers [20], sewage [21,22], and marine waters [23-26]. This review summarizes the knowledge on the spread of CR outside of the clinical setting with particular focus on the potential of the marine environment to act as a reservoir for the genetic transfer of CR among bacteria.

\section{Mechanisms of Carbapenem Resistance}

Compared to penicillins and cephalosporins, carbapenems have an overall broader antimicrobial spectrum [27]. Generally, carbapenems enter bacteria through porins, and after passing the periplasmic space, acylate penicillin-binding proteins (PBPs), which stops the formation of peptidoglycan as well as the cell wall, ultimately leading to cell lysis [28]. A key factor in the efficacy of carbapenems is their ability to bind to multiple different PBPs [15].

Structural changes in or mutations of PBPs, which typically occur in Gram-positive cocci, can contribute to CR. Alterations in affinity, the expression of efflux pumps, and the aberrant production of carbapenemases may also promote CR [15,17]. Several carbapenemresistant bacteria (CRB), such as Klebsiella pneumoniae, Acinetobacter baumannii, and Pseudomonas aeruginosa, are known to possess a combination of these resistance mechanisms [15]. Additionally, alteration in porins or membrane protein functions can lead to reduced diffusion of carbapenem into the periplasm [29]. This has been observed in K. pneumoniae, which acquired CR through a lack of the outer membrane proteins OmpK35 and OmpK36 [30]. Mutations of the regulator gene marR and lack of $\mathrm{OmpF}$ and $\mathrm{OmpC}$ porins have also been correlated with CR in Escherichia coli strains from clinical samples [31].

Carbapenemases can hydrolyse almost all $\beta$-lactam antibiotics, including penicillins, cephalosporins, monobactams, and carbapenems [16]. The expression of carbapenemases seems to play an important role in the spread of CR [28,32]. The wide range of resistance phenotypes observed among carbapenemase-producing isolates is associated with the level of enzyme expression and other resistant mechanisms, such as the expression of other $\beta$-lactamases, efflux pumps, or altered permeability $[17,33]$.

Carbapenemases are divided into two major types, serine carbapenemases and metallo$\beta$-lactamases, which have serine and zinc ions at their active sites, respectively [16]. Serine carbapenemases are mostly chromosomally encoded [34-36], and metallo- $\beta$-lactamases are often found on plasmids [37-39], although recent studies have reported that this pattern has shifted, with both classes being plasmid-encoded [19,40-42]. The metallo- $\beta$-lactamases are characterized by their ability to hydrolyse extended-spectrum cephalosporins (cefotaxime, ceftazidime, and cefepime) [43]. The hydrolysis ability is determined by the interaction of zinc ions on their active site and the $\beta$-lactams [44]. New Delhi Metallo- $\beta$-lactamase (NDM) is the latest type of metallo- $\beta$-lactamase to be identified. NDM- 1 is the major variant and is found mostly in Enterobacteriaceae [45]. It was first described in K. pneumoniae and E. coli isolates in 2008 in Sweden from an Indian patient transferred from a New Delhi hospital $[45,46]$. The $b l a_{\mathrm{NDM}-1}$ gene can be carried by different plasmid types (IncA/C, IncF, and IncL/M), and in rare cases, is chromosomally integrated [45]. In addition, most plasmids with $b l a_{\mathrm{NDM}-1}$ genes harbor a variety of other resistance genes, such as $b l a_{\mathrm{TEM}-1}, b l a_{\mathrm{OXA}-1}, b l a_{\mathrm{OXA}-10}$, and $b l a_{\mathrm{CMY}}$ (encoding various $\beta$-lactamases); $q n r A 6$ and $q n r B 1$ (encoding quinolone resistance); arr-2 (encoding rifampicin resistance); sul-2 (encoding 
sulphonamide resistance); $c m l A$ (encoding chloramphenicol resistance); and ereC (encoding macrolide resistance) [45].

\section{Epidemiology and Distribution of Carbapenem Resistance}

The CDC reports that the highest mortality rate related to AR occurs in healthcare settings, including hospitals. Hospitals are one of a number of sources of organisms with multiple AR, so-called "superbugs", which create a broad concern for public health. Carbapenemase-resistant Enterobacteriaceae have been highlighted as a source of life-threatening nosocomial infection [16], and the epidemiological status of CRB is progressively worsening. Giske et al. reported that in Europe, an outbreak of CR that occurred during the 2000s in several Mediterranean countries was caused mainly by carbapenemaseproducing $P$. aeruginosa [47]. In addition, the OXA-48-like enzymes and NDM-producing Enterobacteriaceae have also spread rapidly in several European countries [47]. In the US, Klebsiella pneumoniae carbapenemase (KPC) is the predominant carbapenemase among Enterobacteriaceae, and the first KPC was isolated from a patient in North Carolina in 1996. Up to 2013, the CDC reported that at least one KPC-producing Enterobacteriaceae had been identified in 46 states and mostly found in K. pneumoniae, E. coli, and Enterobacter spp. [48]. In Australia, CRGs encoding KPC, imipenem-hydrolysing $\beta$-lactamase (IMP), NDM, or oxacillin-hydrolysing carbapenemase (OXA) have been identified in human pathogens. A plasmid-mediated $b l a_{\mathrm{NDM}-5}$ was identified in an $E$. coli isolate from a urine sample of a patient in Brisbane [49]. Isolates belonging to species Serratia marcescens, K. pneumoniae, P. aeruginosa, E. coli, and Enterobacter cloacae and containing IMP-4 resistance genes were recovered from different patients hospitalized in Melbourne [50]. In addition, multiple CRGs (e.g., bla $a_{\mathrm{IMP}-4}$ and bla $a_{\mathrm{OXA}-58}$ ) were also found in an Acinetobacter junii isolate from a blood sample in Melbourne [51]. Furthermore, some carbapenemases were also isolated from Enterobacteriaceae species found in various animals and in healthy humans [52]. These carbapenemases included KPC, OXA NDM, VIM, OXA, IMP from Citrobacter spp., Cronobacter sakazakii, Enterobacter spp., E. coli, Klebsiella oxytoca, K. pneumoniae, Morganella spp., Proteus spp., Providencia spp., and Salmonella spp. [52-55].

Aside from human-populated environments, CR can also spread into the natural milieu, including aquatic environments [42,56-58]. CRGs, such as bla $a_{\mathrm{NDM}-1}, b l a_{\mathrm{KPC}-2}$, and bla $a_{\mathrm{OXA}-58}$, have also been reported in known environmental bacteria, such as Acinetobacter johnsonii [59] and Acinetobacter towneri [60]. Imipenem-hydrolysing $\beta$-lactamase- 2 has also been found in Enterobacter asburiae isolated from USA rivers [32]. A novel carbapenemase, BIC-2, was identified in water samples from the Seine River, Paris. This enzyme was found in Pseudomonas fluorescens and shares $68 \%$ amino acid identity with SFC-1 from Serratia fonticola, and 59\% with plasmid-encoded KPC-2 [61].

There are several ways for CR to enter the environment. These include, for example, wastewater treatment plants (WWTPs), especially those receiving wastewater from hospitals $[21,62,63]$. WWTPs can release large numbers of ARB into the environment, where they might temporarily survive and even proliferate $[7,8,64]$. WWTPs typically do not remove antibiotic-resistance genes (ARGs), but instead may spread them into the aquatic environment $[8,56,65]$. For example, a study in Spain detected clinically relevant ARGs in biofilms and river sediments that were distant to WWTP discharge points [7]. Carbapenemase-producing Enterobacteriaceae (CPE), Acinetobacter spp., Aeromonas spp., and Pseudomonas spp. containing the genes $b l a_{\mathrm{NDM}}, b l a_{\mathrm{KPC}}$, and $b l a_{\mathrm{OXA}}$ have also been isolated from raw sewage, treated effluent, and the receiving river waters $[56,63]$. WWTPs can, therefore, play a significant role in the dissemination of CRB and CRGs.

The further circulation of CR in aquatic matrices may potentially pollute rivers and drinking water sources [66]. A novel class B metallo- $\beta$-lactamase was also identified in Shigella boydii, Aeromonas caviae, and Vibrio cholerae from seepage and drinking water samples [67]. Multi-resistant bacteria and ARGs were detected at a drinking water intake at Lake Geneva, Switzerland, which was $3.2 \mathrm{~km}$ away from a WWTP outlet [68]. Furthermore, CRB have also been found in drinking water in several parts of the world. For instance, 
carbapenemase-producing Serratia fonticola was reported in drinking water in Portugal [69], and CPE including E. coli, Kluyvera, Providencia, Klebsiella, and Citrobacter species, and non-fermenting Gram-negative species, such as Shewanella spp., Pseudomonas spp., and Acinetobacter spp., were found to contain blaOXA-48-type carbapenemase in USA drinking waters [66]. In addition, non-fermenting Gram-negative rods carrying the $b l a_{\mathrm{NDM}}$ gene were isolated from New Delhi drinking water [67]. Thus, the aquatic environments may serve as a vehicle by which CRB or CRGs could be disseminated from one aquatic ecosystem to another (see Figure 1).

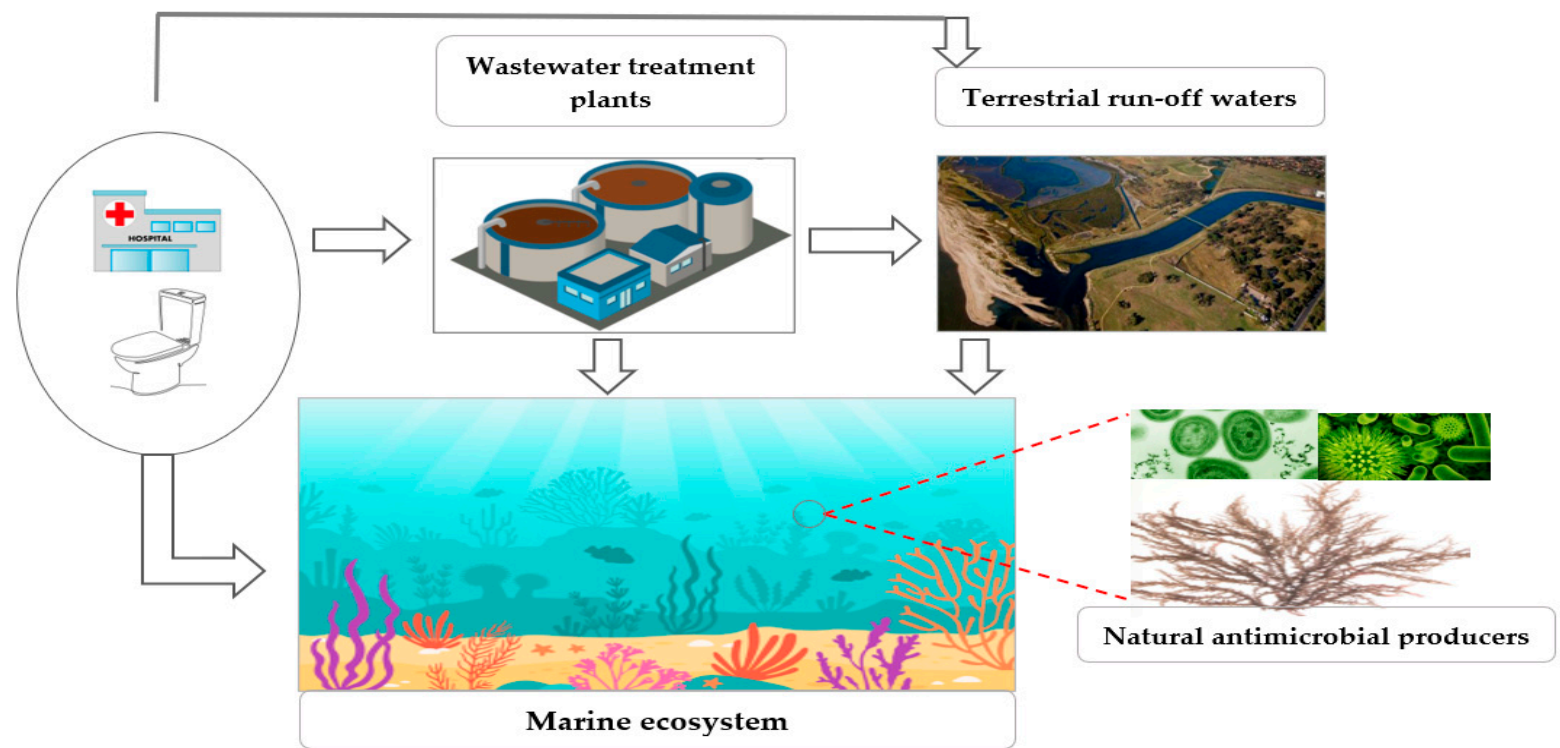

Figure 1. Graphical diagram of the spread of CRB (carbapenem-resistant bacteria) or CRGs (carbapenem-resistant genes) into the marine environment. The diversity of CRB or CRGs in the seawater can be sourced from the human communities and loaded into the marine matrices either via direct sewage disposals or via the outfall of wastewater treatment plants. The marine coastal environment may also receive CR (carbapenem resistance) from polluted rivers and other terrestrial run-off waters. The occurrence of $\mathrm{CR}$ in the ocean can be due to the selection pressure of natural $\beta$-lactam antibiotics produced by other marine microorganisms.

The dense bacterial communities in WWTPs can also facilitate genetic exchange between bacteria, which can lead to the horizontal transfer of resistance genes between clinical pathogens and environmental microorganisms or vice versa $[7,70]$. For example, Citrobacter freundii and Enterobacter cloacae detected in hospital sewage have been found to contain the same bla $a_{\mathrm{KPC}-2}$ gene [71]. The species Pseudomonas monteilii, Brevundimonas diminuta, and Enterobacter ludwigii have been found to contain the same genetic variant of the bla $a_{\text {VIM-13 }}$ gene in sewage [22]. Finding identical CRGs in different bacterial taxa indicates that sewage is a suitable environment for horizontal resistance gene transfer.

\section{Distribution of Carbapenem Resistance in Marine Systems}

The dissemination of AR in seawater may be influenced by discharges from coastal runoff, aquaculture, polluted rivers, and WWTP effluents, which frequently contain resistant bacteria and resistant genes [72-77]. A study described that CRB communities in seawater and storm water samples did not differ significantly at the investigated sites, and the phylogenetic analysis showed that their CR isolates often belonged to the same

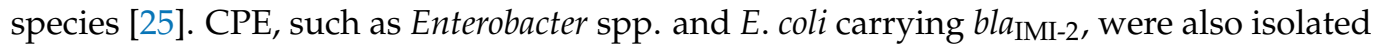
from river estuaries and beach water. Further molecular analysis and genome comparisons revealed the high similarity of these riverine and marine CRB from samples that were collected one month apart [77]. Thus, local sources, such as stormwaters and rivers, are an important source of CRB in the seawater and may have a significant effect on the composition of CRB in the marine environment (see Figure 1). 
Furthermore, CR has also been recently detected in the marine environment [25,73,76,78-80]. For example, CRB belonging to a wide range of bacterial taxa, including four phyla, eight classes, and 30 genera, were found in Australian marine and near-shore environments [25]. Many genera found in the marine environment, such as Pseudomonas [9,81], Stenotrophomonas [81], Acinetobacter [51,82,83], Brevundimonas [84], Caulobacter [85], Chryseobacterium [86,87], Empedobacter [88], Sphingomonas [86], Flavobacterium [89], Cupriavidus [81], Myroides [89], Ochrobactrum [90], and Pedobacter [86], have already been previously described to contain $\mathrm{CR}$, and these bacteria may carry well-known and clinically relevant CRGs. For example, clinically relevant CRGs, such as KPC-2, Guiana extended spectrum (GES)-like, and OXA-carbapenemases, have been identified in several species, including Klebsiella spp., Citrobacter spp., Kluyvera spp., Enterobacter cloacae, E. kobei, E. asburiae, Aeromonas punctata, and A. hydrophila isolated from coastal water [73,91]. In addition, NDM genes have also been detected in K. pneumoniae and E. coli from beach waters [91-93]. Worryingly, CPE, Acinetobacter spp., Aeromonas spp., and Pseudomonas spp. from recreational beach waters have been consistently found throughout the year to carry multiple CRGs, including KPC, GES-like carbapenemase, NDM, IMP, Verona integron-encoded metallo- $\beta$ lactamases (VIM), Sao Paulo metallo- $\beta$-lactamases (SPM), and OXA-carbapenemase [76] (see Table 1). These studies show that clinically relevant CRGs have entered the marine environment and potentially spread into other bacteria.

Table 1. Carbapenem-resistant bacteria and carbapenem resistance genes found in coastal environments.

\begin{tabular}{|c|c|c|}
\hline Carbapenem Resistant Bacteria & $\begin{array}{c}\text { Carbapenem Resistance } \\
\text { Determinants }\end{array}$ & Reference \\
\hline Vibrio cholerae & Not identified & [24] \\
\hline Rheinheimera spp. & B3-MBL & \multirow{2}{*}{ [25] } \\
\hline Variovorax spp. & NDM & \\
\hline Enterobacteriaceae & KPC, OXA & [72] \\
\hline Citrobacter sp., Citrobacter sp., Kluyvera sp., Aeromonas sp. & KPC-2 & [73] \\
\hline Acinetobacter spp. & OXA & \multirow{7}{*}[76]{} \\
\hline Aeromonas spp. & KPC-2, GES-5, GES-16 & \\
\hline Citrobacter sp. & KPC-2, OXA-370 & \\
\hline Enterobacter spp. & KPC-2, KPC-26, GES-5, GES-16 & \\
\hline Klebsiella spp. & KPC-2, KPC-26, GES-16, NDM-1 & \\
\hline Kluyvera spp., Serratia spp. & KPC-2 & \\
\hline Pseudomonas spp. & VIM-2, SPM-1 & \\
\hline Enterobacter asburiae & IMI-2 & \multirow{3}{*}[77]{} \\
\hline Enterobacter bugandensis & IMI-20 & \\
\hline Escherichia coli & OXA-48 & \\
\hline Erythrobacter litoralis & ElBla2* & [78] \\
\hline Enterobacter cloacae & KPC-2, CTX-M-15, OXA-17 & [79] \\
\hline Pelagibacterium halotolerans & $\mathrm{PH}-1 *$ & [80] \\
\hline Aeromonas punctata, Enterobacter asburiae, K. pneumoniae, Enterobacter kobei & KPC, GES-16, OXA-48-like & [91] \\
\hline K. pneumoniae & NDM & [93] \\
\hline K. pneumoniae & NDM-1, OXA-1 & [92] \\
\hline $\begin{array}{c}\text { Pseudomonas spp., Rheinheimera spp., Stenotrophomonas sp., Shewanella sp., } \\
\text { Raoultella sp., Vibrio sp., Pseudoalteromonas sp., Algoriphagus sp., } \\
\text { Bowmanella sp., and Thalassospira sp. }\end{array}$ & OXA-58 & [94] \\
\hline E. coli, K. pneumoniae & OXA-48 & [95] \\
\hline Shewanella livingstonensis & SLB-1* & \multirow{2}{*}{ [96] } \\
\hline Shewanella frigidimarina & SFB-1* & \\
\hline Aliivibrio salmonicida & ALI-1* & [97] \\
\hline
\end{tabular}

* Novel metallo- $\beta$-lactamase. 


\section{Potential for CR Transfer and Reservoir in the Marine Environment}

The marine environment may contribute to the further dissemination of CRGs between different bacterial strains by providing a medium in which horizontal gene transfer can take place $[98,99]$. For example, a study of CR in the coastal environment found that most of the CR aquatic isolates were assigned to the genus Pseudomonas, including the species P. asplenii, P. monteilii, P. fulva, P. plecoglossicida, P. stutzeri, P. taiwanensis, and P. xanthomarina. In the genus Pseudomonas (family Pseudomonadaceae), the production of carbapenemases, such as IMP, VIM, NDM, and KPC, is considered to be the predominant mechanism underlying CR $[9,18,100,101]$. The CRGs are frequently located in the mobile genetic elements, which facilitate their horizontal transfer between different species [102-105]. Thus, horizontal gene transfer might have been involved in the dissemination of CRGs in the Pseudomonas species, similar to what has been observed in the family Enterobacteriaceae $[40,41,106,107]$.

Several CRGs, such as $b l a_{\mathrm{KPC}}, b l a_{\mathrm{NDM}}, b l a_{\mathrm{GES}}$, and $b l a_{\mathrm{OXA} 48 \text {-like, }}$ have been found in different members of Enterobacteriaceae, including K. pneumoniae, Aeromonas punctata, A. hydrophila, E. coli, E. cloacae, E. kobei, and E. asburiae, in recreational seawaters [91,93]. Furthermore, E. coli from terrestrial sources could transfer its bla $a_{\mathrm{CTX}-\mathrm{M}-15}$ gene to Pantoea agglomerans and Raoultella terrigena in the coastal seawater [108]. Another study reported that in seawater samples, Rheinheimera spp., which are typical marine bacteria $[109,110]$, have been found to share an identical MBL gene utilizing plasmid transfer and chromosomal integration with the species $C$. freundii and E. cloacae, which are not typically found in seawater [25]. In addition, Variovorax spp. carried the NDM-type genes, which were likely acquired from the species E. coli, K. pneumoniae, and A. baumannii. These utilized plasmids have also been reported in this coastal water study [25].

Marine samples have also been found to house CRB from genera such as Chromobacterium, Rheinheimera, Variovorax, Aquiflexum, Chitinophaga, Herbaspirillum, and Xanthobacter, which have not previously been known to have CR, indicating the potential for new resistance genes [25]. As marine environments are not usually exposed to high concentrations of clinically relevant carbapenems or other $\beta$-lactam antibiotics [111,112], marine bacteria may evolve novel CR due to the selection pressure of natural $\beta$-lactam antibiotics produced by other marine microorganisms $[113,114]$. This could, for example, include aureoverticillactam and lajollamycin found in the marine species Streptomyces aureoverticillatus [115] and S. nodosus [116], respectively (see Figure 1). As such, several novel carbapenemases have been recently discovered. These include ElBla2 MBL from the species Erythrobacter litoralis (family Sphingomonadaceae), which has an amino acid sequence similarity to NDM-1 [78]; the PH-1 MBL gene from the species Pelagibacterium halotolerans (family Hyphomicrobiaceae) [80]; and the RH-B3-MBL gene from the genus Rheinheimera (family Chromatiaceae) [25]. These findings provide further evidence that the marine environment represents an unexplored reservoir of novel carbapenemases.

\section{The Effect of Marine CRGs/CRB on Human Health}

To date, the impact of pathogenic CRB has been extensively studied within the healthcare setting $[33,48,49]$. However, several bacteria relevant to human health with CR, including Pseudomonas fulva, Brevundimonas vesicularis, Enterococcus durans, Acinetobacter junii, A. johnsonii, Microbacterium lacus, and S. maltophilia, have been found in coastal seawater in Australia [25]. These species have been found to cause human infections, such as bacteraemia (Acinetobacter junii, A. johnsonii, Pseudomonas fulva, and Brevundimonas vesicularis) [117-120], meningitis (P. fulva) [100], endocarditis (E. durans) [121], cellulitis, soft tissue, urinary and respiratory tract infections (Stenotrophomonas maltophilia, Microbacterium lacus) [122-125], and eye infections (S. maltophilia and A. junii) [126,127].

In addition, there is growing evidence that CRGs have been carried by human opportunistic pathogens into seawaters [73,80,94]. For example, CRGs, such as KPC, IMP, VIM, SPM, NDM, and OXA-carbapenemases, have been identified in E. coli, K. pneumoniae, Acinetobacter spp., Aeromonas spp., Enterobacter spp., and Pseudomonas spp. in recreational coastal waters of Rio de Janeiro [73,76], Israel [77], and Ireland [95]. 
This prevalence has public health implications [26,86], since coastal waters are frequently used for recreational and sport purposes. CR infections can, in such circumstances, be acquired through common routes of pathogen exposure to humans, including ingestion, inhalation, and dermal or eye contact with the beach waters [128,129] (see Figure 2). For example, the risk of experiencing symptoms of gastrointestinal, ear, and skin infections from exposure to seawater with bacterial contamination is higher in bathers than in non-bathers $[26,129]$. Open wounds in soft tissues are also vulnerable to infection by opportunistic human pathogens. For example, a soft tissue infection by Microbacterium lacus was acquired after a bather's elbow was bumped on a rock while swimming [124]. Considering the spread of CRB in marine environments that are frequently used for human activities, the potential risk of CRB transfer from this reservoir to humans is still great. Further in-depth studies to quantify the risk of human infection with these CRB in recreational seawater should be performed.

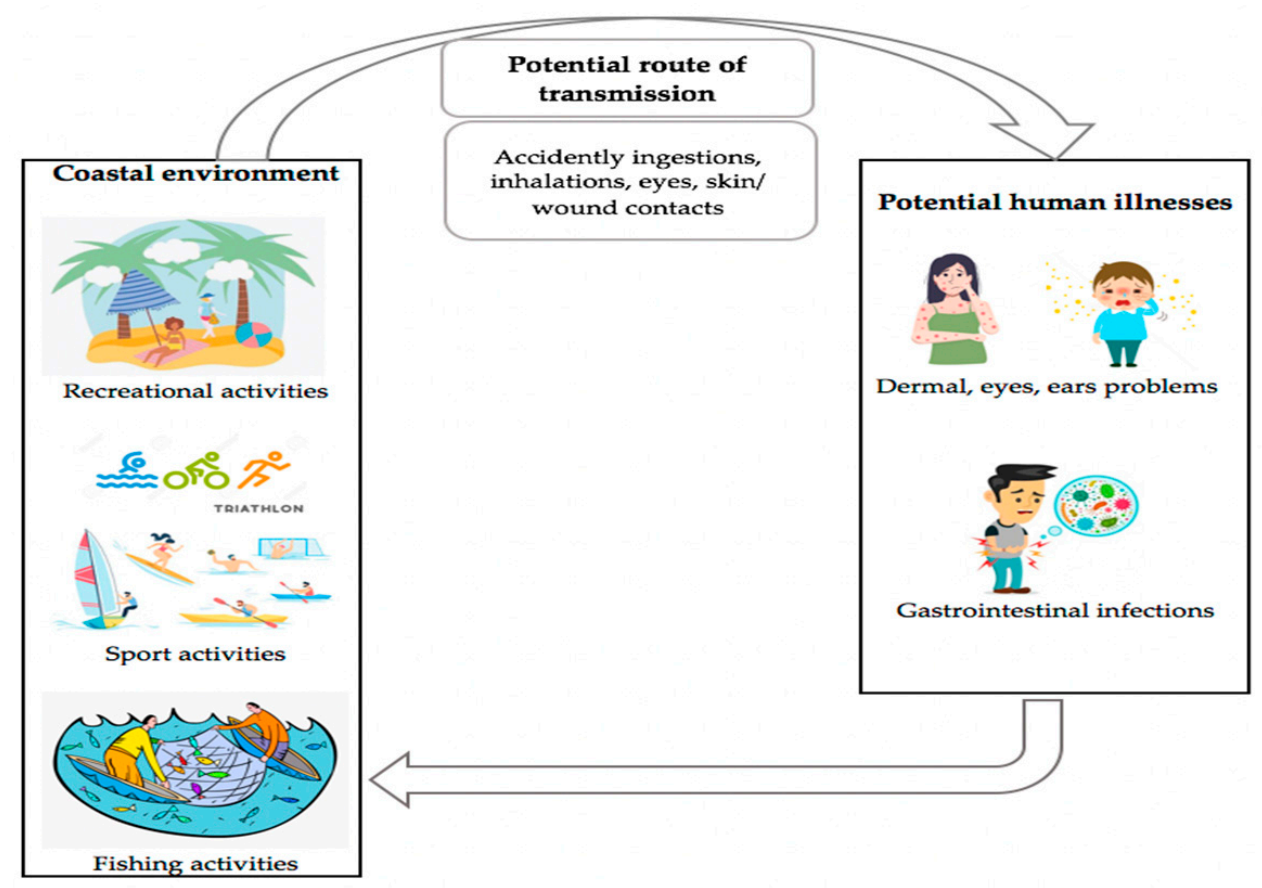

Figure 2. Schematic diagram showing the route of potential CRB transmission from the coastal environment to humans and the potential health problems that may occur. The practice of recreational activities, such as sport and fishing, in CR-contaminated coastal environments may result in potential human illnesses, such as dermal or eye problems and gastrointestinal infections. The possible routes of transmission include accidentally ingested or inhaled beach waters that are contaminated by CR.

\section{Conclusions}

The global spread of CR is becoming a major threat to public health and has worsened with the detection of resistance in last-line antibiotics, including carbapenems $[1,15,16]$. CR has not only been reported in pathogenic bacteria $[6,9,10,31,130]$, but also in environmentally derived bacteria [86,108,131,132]. As non-clinical environments, such as sewage, rivers, lakes, and oceans, may serve as the media for the transmission of CR [24,73,76,133,134], studies of the further dissemination of CR in these matrices are critically important. In the coastal environment, CRB and CRGs seem to be transported from terrestrial sources through stormwater runoff, wastewater discharges, and polluted rivers [21,25,42,57], which had a significant effect on the diversity and CRB load in the marine environment.

To date, a large variety of CRGs have been identified, and the transfer of CRGs between different bacteria has been characterized [22,49,135]. Most CRGs are located on mobile genetic elements, such as plasmids or transposons, and their mobility contributes to the rapid spread of CRGs between bacteria $[16,136]$. The identification of CRGs, including 
novel carbapenemases in non-targeted marine bacteria $[25,78,80]$, suggests either that CRGs have been horizontally transferred from non-marine bacteria (e.g., fecal contaminant) to marine bacteria or that novel CRGs have evolved in marine lineages due to continuing selection by naturally produced $\beta$-lactam antibiotics in the marine environment.

Given that the CRB identified in coastal environments are relevant to human health, public health concerns may arise due to the fact that beach water is mostly designated for recreational and sporting activities [24,26,73,137]. Future investigation of CR in the coastal environment is necessary to understand the resistant epidemiology and quantify the potential risk for CRB to cause human illnesses.

Author Contributions: D.A.P.R.D., T.T., A.M.A.M., N.S.M.N., S.B.Z., and N.H.S. drafted, revised, and approved the manuscript. All authors have read and agreed to the published version of the manuscript.

Funding: This research received no external funding.

Institutional Review Board Statement: Not applicable.

Informed Consent Statement: Not applicable.

Data Availability Statement: No new data were created or analyzed in this study. Data sharing is not applicable to this article.

Acknowledgments: Authors would like to thank CMSI staff and students for helpful discussions.

Conflicts of Interest: The authors declare no conflict of interest.

\section{References}

1. WHO. Global Action Plan on Antimicrobial Resistance; World Health Organization: Geneva, Switzerland, 2015; pp. 1-28.

2. Centres for Disease Control and Prevention. Antibiotic Resistance Threats in the United States. 2013. Available online: https: / / www.cdc.gov/drugresistance/pdf/ar-threats-2013-508.pdf (accessed on 20 January 2021).

3. Humphreys, G.; Fleck, F. United Nations Meeting on Antimicrobial Resistance. World Health Organ. Bull. World Health Organ. 2016, 94, 638.

4. de Kraker, M.E.A.; Stewardson, A.J.; Harbarth, S. Will 10 Million People Die a Year due to Antimicrobial Resistance by 2050? PLoS Med. 2016, 13, e1002184. [CrossRef]

5. World Health Organization. Antimicrobial Resistance. Available online: https://www.who.int/news-room/fact-sheets/detail/ antimicrobial-resistance (accessed on 13 February 2021).

6. Chavda, K.D.; Chen, L.; Fouts, D.E.; Sutton, G.; Brinkac, L.; Jenkins, S.G.; Bonomo, R.A.; Adams, M.D.; Kreiswirth, B. Comprehensive Genome Analysis of Carbapenemase-Producing Enterobacter spp.: New Insights into Phylogeny, Population Structure, and Resistance Mechanisms. mBio 2016, 7, e02093-16. [CrossRef]

7. Marti, E.; Jofre, J.; Balcazar, J.L. Prevalence of Antibiotic Resistance Genes and Bacterial Community Composition in a River Influenced by a Wastewater Treatment Plant. PLoS ONE 2013, 8, e78906. [CrossRef] [PubMed]

8. Mokracka, J.; Koczura, R.; Kaznowski, A. Multiresistant Enterobacteriaceae with class 1 and class 2 integrons in a municipal wastewater treatment plant. Water Res. 2012, 46, 3353-3363. [CrossRef] [PubMed]

9. Ocampo-Sosa, A.A.; Guzmán-Gómez, L.P.; Fernández-Martínez, M.; Román, E.; Rodríguez, C.; Marco, F.; Vila, J.; Martínez-Martínez, L. Isolation of VIM-2-Producing Pseudomonas monteilii Clinical Strains Disseminated in a Tertiary Hospital in Northern Spain. Antimicrob. Agents Chemother. 2015, 59, 1334-1336. [CrossRef] [PubMed]

10. Shin, J.; Baek, J.Y.; Cho, S.Y.; Huh, H.J.; Lee, N.Y.; Song, J.-H.; Chung, D.R.; Ko, K.S. bla NDM-5 -Bearing IncFII-Type Plasmids of Klebsiella pneumoniae Sequence Type 147 Transmitted by Cross-Border Transfer of a Patient. Antimicrob. Agents Chemother. 2016, 60, 1932-1934. [CrossRef]

11. Falagas, M.E.; Lourida, P.; Poulikakos, P.; Rafailidis, P.I.; Tansarli, G.S. Antibiotic Treatment of Infections Due to CarbapenemResistant Enterobacteriaceae: Systematic Evaluation of the Available Evidence. Antimicrob. Agents Chemother. 2014, 58, 654-663. [CrossRef]

12. Fritzenwanker, M.; Imirzalioglu, C.; Herold, S.; Wagenlehner, F.M.; Zimmer, K.P.; Chakraborty, T. Treatment Options for Carbapenem-Resistant Gram-Negative Infections. Dtsch. Ärzteblatt Int. 2018, 115, 345-352. [CrossRef]

13. Trecarichi, E.M.; Tumbarello, M. Therapeutic options for carbapenem-resistant Enterobacteriaceae infections. Virulence 2017, 8, 470-484. [CrossRef] [PubMed]

14. Davies, J.; Davies, D. Origins and Evolution of Antibiotic Resistance. Microbiol. Mol. Biol. Rev. 2010, 74, 417-433. [CrossRef]

15. Papp-Wallace, K.M.; Endimiani, A.; Taracila, M.A.; Bonomo, R.A. Carbapenems: Past, Present, and Future. Antimicrob. Agents Chemother. 2011, 55, 4943-4960. [CrossRef] [PubMed] 
16. Poirel, L.; Pitout, J.D.; Nordmann, P. Carbapenemases: Molecular diversity and clinical consequences. Future Microbiol. 2007, 2, 501-512. [CrossRef]

17. Queenan, A.M.; Bush, K. Carbapenemases: The Versatile beta-Lactamases. Clin. Microbiol. Rev. 2007, 20, 440-458. [CrossRef] [PubMed]

18. Fuste, E.; López-Jiménez, L.; Segura, C.; Gainza, E.; Vinuesa, T.; Vinas, M. Carbapenem-resistance mechanisms of multidrugresistant Pseudomonas aeruginosa. J. Med. Microbiol. 2013, 62, 1317-1325. [CrossRef]

19. Partridge, S.R.; Ginn, A.N.; Wiklendt, A.M.; Ellem, J.; Wong, J.S.J.; Ingram, P.; Guy, S.; Garner, S.; Iredell, J.R. Emergence of blaKPC carbapenemase genes in Australia. Int. J. Antimicrob. Agents 2015, 45, 130-136. [CrossRef]

20. Tacão, M.; Correia, A.; Henriques, I.S. Low Prevalence of Carbapenem-Resistant Bacteria in River Water: Resistance Is Mostly Related to Intrinsic Mechanisms. Microb. Drug Resist. 2015, 21, 497-506. [CrossRef]

21. Lamba, M.; Graham, D.W.; Ahammad, S.Z. Hospital Wastewater Releases of Carbapenem-Resistance Pathogens and Genes in Urban India. Environ. Sci. Technol. 2017, 51, 13906-13912. [CrossRef]

22. Scotta, C.; Juan, C.; Cabot, G.; Oliver, A.; Lalucat, J.; Bennasar, A.; Albertí, S. Environmental Microbiota Represents a Natural Reservoir for Dissemination of Clinically Relevant Metallo-beta-Lactamases. Antimicrob. Agents Chemother. 2011, 55, 5376-5379. [CrossRef] [PubMed]

23. Søraas, A.; Sundsfjord, A.; Sandven, I.; Brunborg, C.; Jenum, P.A. Risk Factors for Community-Acquired Urinary Tract Infections Caused by ESBL-Producing Enterobacteriaceae-A Case-Control Study in a Low Prevalence Country. PLoS ONE 2013, 8, e69581. [CrossRef] [PubMed]

24. Bier, N.; Schwartz, K.; Guerra, B.; Strauch, E. Survey on antimicrobial resistance patterns in Vibrio vulnificus and Vibrio cholerae non-O1/non-O139 in Germany reveals carbapenemase-producing Vibrio cholerae in coastal waters. Front. Microbiol. 2015,6 , 1179. [CrossRef]

25. Dewi, D.A.P.R.; Götz, B.; Thomas, T. Diversity and Genetic Basis for Carbapenem Resistance in a Coastal Marine Environment. Appl. Environ. Microbiol. 2020, 86, e02939-19. [CrossRef]

26. Leonard, A.F.C.; Singer, A.; Ukoumunne, O.C.; Gaze, W.H.; Garside, R. Is it safe to go back into the water? A systematic review and meta-analysis of the risk of acquiring infections from recreational exposure to seawater. Int. J. Epidemiol. 2018, 47, 572-586. [CrossRef]

27. Bassetti, M.; Nicolini, L.; Esposito, S.; Righi, E.; Viscoli, C. Current Status of Newer Carbapenems. Curr. Med. Chem. 2009, 16, 564-575. [CrossRef] [PubMed]

28. Kattan, J.N.; Villegas, M.V.; Quinn, J.P. New developments in carbapenems. Clin. Microbiol. Infect. 2008, 14, 1102-1111. [CrossRef] [PubMed]

29. Little, M.L.; Qin, X.; Zerr, D.M.; Weissman, S.J. Molecular diversity in mechanisms of carbapenem resistance in paediatric Enterobacteriaceae. Int. J. Antimicrob. Agents 2012, 39, 52-57. [CrossRef]

30. Sho, T.; Muratani, T.; Hamasuna, R.; Yakushiji, H.; Fujimoto, N.; Matsumoto, T. The Mechanism of High-Level Carbapenem Resistance in Klebsiella pneumoniae: Underlying Ompk36-Deficient Strains Represent a Threat of Emerging High-Level CarbapenemResistantK. pneumoniaewith IMP-1 ß-Lactamase Production in Japan. Microb. Drug Resist. 2013, 19, 274-281. [CrossRef] [PubMed]

31. Warner, D.M.; Yang, Q.; Duval, V.; Chen, M.; Xu, Y.; Levy, S.B. Involvement of MarR and YedS in Carbapenem Resistance in a Clinical Isolate of Escherichia coli from China. Antimicrob. Agents Chemother. 2013, 57, 1935-1937. [CrossRef]

32. Aubron, C.; Poirel, L.; Ash, R.J.; Nordmann, P. Carbapenemase-producing Enterobacteriaceae, U.S. Rivers. Emerg. Infect. Dis. 2005, 11, 260-264. [CrossRef]

33. Nordmann, P.; Dortet, L.; Poirel, L. Carbapenem resistance in Enterobacteriaceae: Here is the storm! Trends Mol. Med. 2012, 18, 263-272. [CrossRef]

34. Naas, T.; Vandel, L.; Sougakoff, W.; Livermore, D.M.; Nordmann, P. Cloning and sequence analysis of the gene for a carbapenemhydrolyzing class A beta-lactamase, Sme-1, from Serratia marcescens S6. Antimicrob. Agents Chemother. 1994, 38, 1262-1270. [CrossRef] [PubMed]

35. Queenan, A.M.; Torres-Viera, C.; Gold, H.S.; Carmeli, Y.; Eliopoulos, G.M.; Moellering, R.C., Jr.; Quinn, J.P.; Hindler, J.; Medeiros, A.A.; Bush, K. SME-Type Carbapenem-Hydrolyzing Class A $\beta$-Lactamases from Geographically Diverse Serratia marcescens Strains. Antimicrob. Agents Chemother. 2000, 44, 3035-3039. [CrossRef] [PubMed]

36. Rasmussen, B.A.; Bush, K.; Keeney, D.; Yang, Y.; Hare, R.; O'Gara, C.; Medeiros, A.A. Characterization of IMI-1 beta-lactamase, a class A carbapenem-hydrolyzing enzyme from Enterobacter cloacae. Antimicrob. Agents Chemother. 1996, 40, 2080-2086. [CrossRef] [PubMed]

37. Giakkoupi, P.; Xanthaki, A.; Kanelopoulou, M.; Vlahaki, A.; Miriagou, V.; Kontou, S.; Papafraggas, E.; Malamou-Lada, H.; Tzouvelekis, L.S.; Legakis, N.J.; et al. VIM-1 Metallo- $\beta$-Lactamase-Producing Klebsiella pneumoniae Strains in Greek Hospitals. J. Clin. Microbiol. 2003, 41, 3893-3896. [CrossRef]

38. Poirel, L.; Héritier, C.; Tolün, V.; Nordmann, P. Emergence of Oxacillinase-Mediated Resistance to Imipenem in Klebsiella pneumoniae. Antimicrob. Agents Chemother. 2004, 48, 15-22. [CrossRef] [PubMed]

39. Tórtola, M.T.; Lavilla, S.; Miró, E.; González, J.J.; Larrosa, N.; Sabaté, M.; Navarro, F.; Prats, G. First Detection of a CarbapenemHydrolyzing Metalloenzyme in Two Enterobacteriaceae Isolates in Spain. Antimicrob. Agents Chemother. 2005, 49, 3492-3494. [CrossRef] [PubMed] 
40. De La Cadena, E.; Correa, A.; Muñoz, J.S.; Rojas, L.J.; Hernández-Gómez, C.; Pallares, C.; Perez, F.; Bonomo, R.A.; Villegas, M.V. Molecular characterisation of carbapenem-resistant Enterobacter cloacae complex in Colombia: bla $a_{\mathrm{KPC}}$ and the 'changing landscape. J. Glob. Antimicrob. Resist. 2018, 13, 184-189. [CrossRef] [PubMed]

41. Li, X.; Zhu, Y.; Shen, M.; Du, J.; Zhang, L.; Wang, D. Draft genome sequence of Enterobacter cloacae HBY, a ST128 clinical strain co-producing KPC-2 and NDM-1 carbapenemases. J. Glob. Antimicrob. Resist. 2018, 12, 1-2. [CrossRef] [PubMed]

42. Nasri, E.; Subirats, J.; Sànchez-Melsió, A.; Ben Mansour, H.; Borrego, C.M.; Balcázar, J.L. Abundance of carbapenemase genes (blaKPC, blaNDM and blaOXA-48) in wastewater effluents from Tunisian hospitals. Environ. Pollut. 2017, 229, 371-374. [CrossRef]

43. Poirel, L.; Le Thomas, I.; Naas, T.; Karim, A.; Nordmann, P. Biochemical Sequence Analyses of GES-1, a Novel Class A ExtendedSpectrum $\beta$-Lactamase, and the Class 1 Integron In52 from Klebsiella pneumoniae. Antimicrob. Agents Chemother. 2000, 44, 622-632. [CrossRef]

44. Bush, K.; Jacoby, G.A.; Medeiros, A.A. A functional classification scheme for beta-lactamases and its correlation with molecular structure. Antimicrob. Agents Chemother. 1995, 39, 1211-1233. [CrossRef] [PubMed]

45. Nordmann, P.; Poirel, L.; Walsh, T.R.; Livermore, D.M. The emerging NDM carbapenemases. Trends Microbiol. 2011, 19, 588-595. [CrossRef]

46. Moellering, R.C., Jr. NDM-1-A Cause for Worldwide Concern. N. Engl. J. Med. 2010, 363, 2377-2379. [CrossRef] [PubMed]

47. Giske, C.G.; Martinez, L.M.; Cantón, R.; Stefani, S.; Skov, R.; Glupczynski, Y.; Nordmann, P.; Wootton, M.; Miriagou, V.; Simonsen, G.S.; et al. EUCAST Guidelines for Detection of Resistance Mechanisms and Specific Resistances of Clinical and/or Epidemiological Importance. 2017. Available online: https:/ / www.eucast.org/fileadmin/src/media/PDFs/EUCAST_files/ Resistance_mechanisms/EUCAST_detection_of_resistance_mechanisms_170711.pdf (accessed on 23 May 2021).

48. Guh, A.Y.; Limbago, B.M.; Kallen, A.J. Epidemiology and prevention of carbapenem-resistant Enterobacteriaceae in the United States. Expert Rev. Anti Infect. Ther. 2014, 12, 565-580. [CrossRef] [PubMed]

49. Wailan, A.M.; Paterson, D.L.; Caffery, M.; Sowden, D.; Sidjabat, H.E. Draft Genome Sequence of NDM-5-Producing Escherichia coli Sequence Type 648 and Genetic Context of bla NDM-5 in Australia. Genome Announc. 2015, 3, e00194-15. [CrossRef] [PubMed]

50. Peleg, A.Y.; Franklin, C.; Bell, J.M.; Spelman, D.W. Dissemination of the Metallo-beta-Lactamase Gene blaIMP-4 among GramNegative Pathogens in a Clinical Setting in Australia. Clin. Infect. Dis. 2005, 41, 1549-1556. [CrossRef]

51. Peleg, A.Y.; Franklin, C.; Walters, L.J.; Bell, J.M.; Spelman, D.W. OXA-58 and IMP-4 Carbapenem-Hydrolyzing beta-Lactamases in an Acinetobacter junii Blood Culture Isolate from Australia. Antimicrob. Agents Chemother. 2006, 50, 399-400. [CrossRef]

52. Köck, R.; Daniels-Haardt, I.; Becker, K.; Mellmann, A.; Friedrich, A.W.; Mevius, D.; Schwarz, S.; Jurke, A. Carbapenem-resistant Enterobacteriaceae in wildlife, food-producing, and companion animals: A systematic review. Clin. Microbiol. Infect. 2018, 24, 1241-1250. [CrossRef]

53. Liu, B.-T.; Song, F.-J.; Zou, M.; Hao, Z.-H.; Shan, H. Emergence of Colistin Resistance Gene mcr-1 in Cronobacter sakazakii Producing NDM-9 and in Escherichia coli from the Same Animal. Antimicrob. Agents Chemother. 2017, 61, e01444-16. [CrossRef]

54. Yousfi, M.; Touati, A.; Muggeo, A.; Mira, B.; Asma, B.; Brasme, L.; Guillard, T.; De Champs, C. Clonal dissemination of OXA48-producing Enterobacter cloacae isolates from companion animals in Algeria. J. Glob. Antimicrob. Resist. 2018, 12, 187-191. [CrossRef]

55. Abraham, S.; O’Dea, M.; Trott, D.J.; Abraham, R.J.; Hughes, D.; Pang, S.; McKew, G.; Cheong, E.Y.L.; Merlino, J.; Saputra, S. Isolation and plasmid characterization of carbapenemase (IMP-4) producing Salmonella enterica Typhimurium from cats. Sci. Rep. 2016, 6, 35527. [CrossRef]

56. Lamba, M.; Gupta, S.; Shukla, R.; Graham, D.W.; Sreekrishnan, T.R.; Ahammad, S.Z. Carbapenem resistance exposures via wastewaters across New Delhi. Environ. Int. 2018, 119, 302-308. [CrossRef]

57. Proia, L.; Anzil, A.; Borrego, C.; Farrè, M.; Llorca, M.; Sanchis, J.; Bogaerts, P.; Balcázar, J.L.; Servais, P. Occurrence and persistence of carbapenemases genes in hospital and wastewater treatment plants and propagation in the receiving river. J. Hazard. Mater. 2018, 358, 33-43. [CrossRef]

58. Yang, F.; Mao, D.; Zhou, H.; Wang, X.; Luo, Y. Propagation of New Delhi Metallo- $\beta$-lactamase Genes (blaNDM-1) from a Wastewater Treatment Plant to Its Receiving River. Environ. Sci. Technol. Lett. 2016, 3, 138-143. [CrossRef]

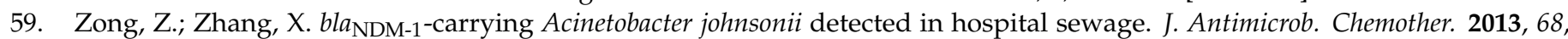
1007-1010. [CrossRef] [PubMed]

60. Jiang, N.; Zhang, X.; Zhou, Y.; Zhang, Z.; Zheng, X. Whole-genome sequencing of an NDM-1- and OXA-58-producing Acinetobacter towneri isolate from hospital sewage in Sichuan Province, China. J. Glob. Antimicrob. Resist. 2019, 16, 4-5. [CrossRef] [PubMed]

61. Girlich, D.; Poirel, L.; Nordmann, P. Novel Ambler Class A Carbapenem-Hydrolyzing $\beta$-Lactamase from a Pseudomonas fluorescens Isolate from the Seine River, Paris, France. Antimicrob. Agents Chemother. 2010, 54, 328-332. [CrossRef] [PubMed]

62. Picão, R.C.; Cardoso, J.P.; Campana, E.H.; Nicoletti, A.G.; Petrolini, F.V.B.; Assis, D.M.; Juliano, L.; Gales, A.C. The route of antimicrobial resistance from the hospital effluent to the environment: Focus on the occurrence of KPC-producing Aeromonas spp. and Enterobacteriaceae in sewage. Diagn. Microbiol. Infect. Dis. 2013, 76, 80-85. [CrossRef] [PubMed]

63. Zhang, L.; Ma, X.; Luo, L.; Hu, N.; Duan, J.; Tang, Z.; Zhong, R.; Li, Y. The Prevalence and Characterization of Extended-Spectrum $\beta$-Lactamase- and Carbapenemase-Producing Bacteria from Hospital Sewage, Treated Effluents and Receiving Rivers. Int. J. Environ. Res. Public Health 2020, 17, 1183. [CrossRef] [PubMed]

64. Cooper, A.L.; Carter, C.; McLeod, H.; Wright, M.; Sritharan, P.; Tamber, S.; Wong, A.; Carrillo, C.D.; Blais, B.W. Detection of carbapenem-resistance genes in bacteria isolated from wastewater in Ontario. FACETS 2021, 6, 569-591. [CrossRef] 
65. Munir, M.; Wong, K.; Xagoraraki, I. Release of antibiotic resistant bacteria and genes in the effluent and biosolids of five wastewater utilities in Michigan. Water Res. 2011, 45, 681-693. [CrossRef] [PubMed]

66. Tanner, W.D.; VanDerslice, J.A.; Goel, R.K.; Leecaster, M.K.; Fisher, M.A.; Olstadt, J.; Gurley, C.M.; Morris, A.G.; Seely, K.A.; Chapman, L. Multi-state study of Enterobacteriaceae harboring extended-spectrum beta-lactamase and carbapenemase genes in U.S. drinking water. Sci. Rep. 2019, 9, 3938. [CrossRef] [PubMed]

67. Walsh, T.R.; Weeks, J.; Livermore, D.M.; Toleman, M.A. Dissemination of NDM-1 positive bacteria in the New Delhi environment and its implications for human health: An environmental point prevalence study. Lancet Infect. Dis. 2011, 11, 355-362. [CrossRef]

68. Czekalski, N.; Berthold, T.; Caucci, S.; Egli, A.; Buergmann, H. Increased Levels of Multiresistant Bacteria and Resistance Genes after Wastewater Treatment and Their Dissemination into Lake Geneva, Switzerland. Front. Microbiol. 2012, 3, 106. [CrossRef] [PubMed]

69. Henriques, I.; Jucá Ramos, R.T.; Baraúna, R.A.; de Sá, P.H.; Marinho Almeida, D.; Carneiro, A.R.; Barbosa, S.; Pereira, A.; Alves, A.; Saavedra, M.J. Draft Genome Sequence of Serratia fonticola UTAD54, a Carbapenem-Resistant Strain Isolated from Drinking Water. Genome Announc. 2013, 1, e00970-13. [CrossRef]

70. Novo, A.; André, S.; Viana, P.; Nunes, O.C.; Manaia, C.M. Antibiotic resistance, antimicrobial residues and bacterial community composition in urban wastewater. Water Res. 2013, 47, 1875-1887. [CrossRef]

71. Zhang, R.; Yang, L.; Cai, J.C.; Zhou, H.W.; Chen, G.-X. High-level carbapenem resistance in a Citrobacter freundii clinical isolate is due to a combination of KPC-2 production and decreased porin expression. J. Med. Microbiol. 2008, 57, 332-337. [CrossRef]

72. Ahmed, W.; Zhang, Q.; Lobos, A.; Senkbeil, J.; Sadowsky, M.J.; Harwood, V.J.; Saeidi, N.; Marinoni, O.; Ishii, S. Precipitation influences pathogenic bacteria and antibiotic resistance gene abundance in storm drain outfalls in coastal sub-tropical waters. Environ. Int. 2018, 116, 308-318. [CrossRef]

73. Montezzi, L.F.; Campana, E.H.; Corrêa, L.L.; Justo, L.H.; Paschoal, R.P.; da Silva, I.L.V.D.; Souza, M.D.C.M.; Drolshagen, M.; Picão, R.C. Occurrence of carbapenemase-producing bacteria in coastal recreational waters. Int. J. Antimicrob. Agents 2015, 45, 174-177. [CrossRef] [PubMed]

74. Rose, J.M.; Gast, R.J.; Bogomolni, A.; Ellis, J.C.; Lentell, B.J.; Touhey, K.; Moore, M. Occurrence and patterns of antibiotic resistance in vertebrates off the Northeastern United States coast. FEMS Microbiol. Ecol. 2009, 67, 421-431. [CrossRef]

75. Sidhu, J.P.S.; Hodgers, L.; Ahmed, W.; Chong, M.N.; Toze, S. Prevalence of human pathogens and indicators in stormwater runoff in Brisbane, Australia. Water Res. 2012, 46, 6652-6660. [CrossRef] [PubMed]

76. Paschoal, R.P.; Campana, E.H.; Corrêa, L.L.; Montezzi, L.F.; Barrueto, L.R.L.; da Silva, I.R.; Bonelli, R.R.; Castro, L.D.S.; Picão, R.C. Concentration and Variety of Carbapenemase Producers in Recreational Coastal Waters Showing Distinct Levels of Pollution. Antimicrob. Agents Chemother. 2017, 61, e01963-17. [CrossRef] [PubMed]

77. Cohen, R.; Paikin, S.; Rokney, A.; Rubin-Blum, M.; Astrahan, P. Multidrug-resistant enterobacteriaceae in coastal water: An emerging threat. Antimicrob. Resist. Infect. Control 2020, 9, 1-9. [CrossRef] [PubMed]

78. Jiang, X.W.; Cheng, H.; Huo, Y.Y.; Xu, L.; Wu, Y.H.; Liu, W.H.; Tao, F.F.; Cui, X.J.; Zheng, B.W. Biochemical and genetic characterization of a novel metallo- $\beta$-lactamase from marine bacterium Erythrobacter litoralis HTCC 2594. Sci. Rep. 2018, 8, 803. [CrossRef]

79. Sellera, F.P.; Fernandes, M.R.; Moura, Q.; Souza, T.A.; Cerdeira, L.; Lincopan, N. Draft genome sequence of Enterobacter cloacae ST520 harbouring bla KPC-2, bla CTX-M-15 and bla OXA-17 isolated from coastal waters of the South Atlantic Ocean. J. Glob. Antimicrob. Resist. 2017, 10, 279-280. [CrossRef]

80. Zheng, B.; Jiang, X.; Xu, Z.; Fang, Y.; Li, L. Characterization of a novel metallo- $\beta$-lactamases fold hydrolase from Pelagibacterium halotolerans, a marine halotolerant bacterium isolated from East China Sea. Extremophiles 2016, 20, 37-44. [CrossRef]

81. Harmon, D.E.; Miranda, O.A.; McCarley, A.; Eshaghian, M.; Carlson, N.; Ruiz, C. Prevalence and characterization of carbapenemresistant bacteria in water bodies in the Los Angeles-Southern California area. Microbiologyopen 2019, 8, e00692. [CrossRef]

82. Marqué, S.; Poirel, L.; Héritier, C.; Brisse, S.; Blasco, M.D.; Filip, R.; Coman, G.; Naas, T.; Nordmann, P. Regional Occurrence of Plasmid-Mediated Carbapenem-Hydrolyzing Oxacillinase OXA-58 in Acinetobacter spp. in Europe. J. Clin. Microbiol. 2005, 43, 4885-4888. [CrossRef]

83. Pillonetto, M.; Arend, L.; Vespero, E.C.; Pelisson, M.; Chagas, T.P.G.; Carvalho-Assef, A.P.D.; Asensi, M.D. First Report of NDM-1-Producing Acinetobacter baumannii Sequence Type 25 in Brazil. Antimicrob. Agents Chemother. 2014, 58, 7592-7594. [CrossRef]

84. Almuzara, M.N.; Barberis, C.M.; Rodríguez, C.H.; Famiglietti, A.M.R.; Ramirez, M.S.; Vay, C.A. First Report of an Extensively Drug-Resistant VIM-2 Metallo- $\beta$-Lactamase-Producing Brevundimonas diminuta Clinical Isolate. J. Clin. Microbiol. 2012, 50, 2830-2832. [CrossRef]

85. Docquier, J.-D.; Pantanella, F.; Giuliani, F.; Thaller, M.C.; Amicosante, G.; Galleni, M.; Frère, J.-M.; Bush, K.; Rossolini, G.M. CAU-1, a Subclass B3 Metallo- $\beta$-Lactamase of Low Substrate Affinity Encoded by an Ortholog Present in the Caulobacter crescentus Chromosome. Antimicrob. Agents Chemother. 2002, 46, 1823-1830. [CrossRef]

86. Gudeta, D.D.; Bortolaia, V.; Amos, G.; Wellington, E.M.H.; Brandt, K.K.; Poirel, L.; Nielsen, J.B.; Westh, H.; Guardabassi, L. The Soil Microbiota Harbors a Diversity of Carbapenem-Hydrolyzing $\beta$-Lactamases of Potential Clinical Relevance. Antimicrob. Agents Chemother. 2016, 60, 151-160. [CrossRef] 
87. Gudeta, D.D.; Pollini, S.; Docquier, J.-D.; Bortolaia, V.; Rossolini, G.M.; Guardabassi, L. Biochemical Characterization of CPS-1, a Subclass B3 Metallo- $\beta$-Lactamase from a Chryseobacterium piscium Soil Isolate. Antimicrob. Agents Chemother. 2016, 60, 1869-1873. [CrossRef] [PubMed]

88. Bellais, S.; Naas, T.; Nordmann, P. Genetic and Biochemical Characterization of CGB-1, an Ambler Class B CarbapenemHydrolyzing $\beta$-Lactamase from Chryseobacterium gleum. Antimicrob. Agents Chemother. 2002, 46, 2791-2796. [CrossRef]

89. Mammeri, H.; Bellais, S.; Nordmann, P. Chromosome-Encoded $\beta$-Lactamases TUS-1 and MUS-1 from Myroides odoratus and Myroides odoratimimus (Formerly Flavobacterium odoratum), New Members of the Lineage of Molecular Subclass B1 Metalloenzymes. Antimicrob. Agents Chemother. 2002, 46, 3561-3567. [CrossRef] [PubMed]

90. Montaña, S.; Schramm, S.T.J.; Traglia, G.M.; Chiem, K.; Parmeciano Di Noto, G.; Almuzara, M.; Barberis, C.; Vay, C.; Quiroga, C.; Tolmasky, M.E. The Genetic Analysis of an Acinetobacter johnsonii Clinical Strain Evidenced the Presence of Horizontal Genetic Transfer. PLoS ONE 2016, 11, e0161528. [CrossRef] [PubMed]

91. de Araujo, C.F.M.; Silva, D.M.; Carneiro, M.T.; Ribeiro, S.; Fontana-Maurell, M.; Alvarez, P.; Asensi, M.D.; Zahner, V.; Carvalho-Assef, A.P.D. Detection of Carbapenemase Genes in Aquatic Environments in Rio de Janeiro, Brazil. Antimicrob. Agents Chemother. 2016, 60, 4380-4383. [CrossRef] [PubMed]

92. Campana, E.H.; Montezzi, L.F.; Paschoal, R.P.; Picão, R.C. NDM-producing Klebsiella pneumoniae ST11 goes to the beach. Int. J. Antimicrob. Agents 2016, 49, 119-121. [CrossRef]

93. Mahon, B.M.; Brehony, C.; McGrath, E.; Killeen, J.; Cormican, M.; Hickey, P.; Keane, S.; Hanahoe, B.; Dolan, A.; Morris, D. Indistinguishable NDM-producing Escherichia coli isolated from recreational waters, sewage, and a clinical specimen in Ireland, 2016 to 2017. Eurosurveillance 2017, 22, 30513. [CrossRef]

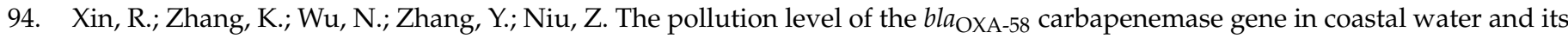
host bacteria characteristics. Environ. Pollut. 2019, 244, 66-71. [CrossRef]

95. Mahon, B.M.; Brehony, C.; Cahill, N.; McGrath, E.; O'Connor, L.; Varley, A.; Cormican, M.; Ryan, S.; Hickey, P.; Keane, S. Detection of OXA-48-like-producing Enterobacterales in Irish recreational water. Sci. Total Environ. 2019, 690, 1-6. [CrossRef]

96. Poirel, L.; Héritier, C.; Nordmann, P. Genetic and biochemical characterization of the chromosome-encoded class B $\beta$-lactamases from Shewanella livingstonensis (SLB-1) and Shewanella frigidimarina (SFB-1). J. Antimicrob. Chemother. 2005, 55, 680-685. [CrossRef] [PubMed]

97. Kristiansen, A.; Grgic, M.; Altermark, B.; Leiros, I. Properties and distribution of a metallo- $\beta$-lactamase (ALI -1$)$ from the fish pathogen Aliivibrio salmonicida LFI $_{1238}$. J. Antimicrob. Chemother. 2015, 70, 766-772. [CrossRef] [PubMed]

98. Hatosy, S.M.; Martiny, A.C.; Nojiri, H. The Ocean as a Global Reservoir of Antibiotic Resistance Genes. Appl. Environ. Microbiol. 2015, 81, 7593-7599. [CrossRef]

99. Suzuki, S.; Pruden, A.; Virta, M.; Zhang, T. Antibiotic Resistance in Aquatic Systems. Front. Microbiol. 2017, 8, 14. [CrossRef] [PubMed]

100. Almuzara, M.N.; Vazquez, M.; Tanaka, N.; Turco, M.; Ramirez, M.S.; Lopez, E.L.; Pasteran, F.; Rapoport, M.; Procopio, A.; Vay, C.A. First Case of Human Infection Due to Pseudomonas fulva, an Environmental Bacterium Isolated from Cerebrospinal Fluid. J. Clin. Microbiol. 2010, 48, 660-664. [CrossRef]

101. Rizek, C.; Fu, L.; Dos Santos, L.C.; Leite, G.; Ramos, J.; Rossi, F.; Guimaraes, T.; Levin, A.S.; Costa, S.F. Characterization of carbapenem-resistant Pseudomonas aeruginosa clinical isolates, carrying multiple genes coding for this antibiotic resistance. Ann. Clin. Microbiol. Antimicrob. 2014, 13, 1-5. [CrossRef]

102. Buehrle, D.J.; Shields, R.K.; Clarke, L.G.; Potoski, B.A.; Clancy, C.J.; Nguyen, M.H. Carbapenem-Resistant Pseudomonas aeruginosa Bacteremia: Risk Factors for Mortality and Microbiologic Treatment Failure. Antimicrob. Agents Chemother. 2017, 61, e01243-16. [CrossRef] [PubMed]

103. Partridge, S.R.; Kwong, S.M.; Firth, N.; Jensen, S.O. Mobile Genetic Elements Associated with Antimicrobial Resistance. Clin. Microbiol. Rev. 2018, 31, e00088-17. [CrossRef] [PubMed]

104. Walsh, T.R.; Toleman, M.A.; Hryniewicz, W.; Bennett, P.M.; Jones, R.N. Evolution of an integron carrying blaVIM-2 in Eastern Europe: Report from the SENTRY Antimicrobial Surveillance Program. J. Antimicrob. Chemother. 2003, 52, 116-119. [CrossRef]

105. Yong, D.; Toleman, M.A.; Bell, J.; Ritchie, B.; Pratt, R.; Ryley, H.; Walsh, T.R. Genetic and Biochemical Characterization of an Acquired Subgroup B3 Metallo- $\beta$-Lactamase Gene, blaAIM-1, and Its Unique Genetic Context in Pseudomonas aeruginosa from Australia. Antimicrob. Agents Chemother. 2012, 56, 6154-6159. [CrossRef]

106. Poirel, L.; Ros, A.; Carricajo, A.; Berthelot, P.; Pozzetto, B.; Bernabeu, S.; Nordmann, P. Extremely Drug-ResistantCitrobacter freundiiIsolate Producing NDM-1 and Other Carbapenemases Identified in a Patient Returning from India. Antimicrob. Agents Chemother. 2011, 55, 447-448. [CrossRef]

107. Goren, M.G.; Chmelnitsky, I.; Carmeli, Y.; Navon-Venezia, S. Plasmid-encoded OXA-48 carbapenemase in Escherichia coli from Israel. J. Antimicrob. Chemother. 2011, 66, 672-673. [CrossRef] [PubMed]

108. Maravić, A.; Skočibušić, M.; Cvjetan, S.; Šamanić, I.; Fredotović, Ž.; Puizina, J. Prevalence and diversity of extended-spectrum- $\beta$ lactamase-producing Enterobacteriaceae from marine beach waters. Mar. Pollut. Bull. 2015, 90, 60-67. [CrossRef]

109. Yoon, J.-H.; Park, S.E.; Kang, S.-J.; Oh, T.-K. Rheinheimera aquimaris sp. nov., isolated from seawater of the East Sea in Korea. Int. J. Syst. Evol. Microbiol. 2007, 57, 1386-1390. [CrossRef] [PubMed] 
110. Romanenko, L.A.; Uchino, M.; Falsen, E.; Zhukova, N.V.; Mikhailov, V.V.; Uchimura, T. Rheinheimera pacifica sp. nov., a novel halotolerant bacterium isolated from deep sea water of the Pacific. Int. J. Syst. Evol. Microbiol. 2003, 53, 1973-1977. [CrossRef] [PubMed]

111. Kümmerer, K. Antibiotics in the aquatic environment-A review-Part I. Chemosphere 2009, 75, 417-434. [CrossRef]

112. Xu, W.; Zhang, G.; Zou, S.; Li, X.; Liu, Y. Determination of selected antibiotics in the Victoria Harbour and the Pearl River, South China using high-performance liquid chromatography-electrospray ionization tandem mass spectrometry. Environ. Pollut. 2007, 145, 672-679. [CrossRef]

113. Genilloud, O.O. Mining Actinomycetes for Novel Antibiotics in the Omics Era: Are We Ready to Exploit This New Paradigm? Antibiotics 2018, 7, 85. [CrossRef]

114. Silber, J.; Kramer, A.; Labes, A.; Tasdemir, D. From Discovery to Production: Biotechnology of Marine Fungi for the Production of New Antibiotics. Mar. Drugs 2016, 14, 137. [CrossRef]

115. Mitchell, S.S.; Nicholson, B.; Teisan, S.; Lam, K.S.; Potts, B.C.M. Aureoverticillactam, a Novel 22-Atom Macrocyclic Lactam from the Marine Actinomycete Streptomyces aureoverticillatus. J. Nat. Prod. 2004, 67, 1400-1402. [CrossRef]

116. Manam, R.R.; Teisan, S.; White, D.J.; Nicholson, B.; Grodberg, J.; Neuteboom, S.T.C.; Lam, K.S.; Mosca, D.A.; Lloyd, G.K.; Potts, B.C.M. Lajollamycin, a Nitro-tetraene Spiro- $\beta$-lactone- $\gamma$-lactam Antibiotic from the Marine Actinomycete Streptomyces nodosus. J. Nat. Prod. 2005, 68, 240-243. [CrossRef]

117. Cayô, R.; San Segundo, L.Y.; del Molino Bernal, I.C.P.; de la Fuente, C.G.; Rodríguez, M.A.B.; Calvo, J.; Martínez-Martínez, L. Bloodstream infection caused by Acinetobacter junii in a patient with acute lymphoblastic leukaemia after allogenic haematopoietic cell transplantation. J. Med. Microbiol. 2011, 60, 375-377. [CrossRef]

118. Linde, H.-J.; Hahn, J.; Holler, E.; Reischl, U.; Lehn, N. Septicemia Due to Acinetobacter junii. J. Clin. Microbiol. 2002, 40, $2696-2697$. [CrossRef] [PubMed]

119. Liu, Y.; Liu, K.; Yu, X.; Li, B.; Cao, B. Identification and control of a Pseudomonas spp (P. fulva and P. putida) bloodstream infection outbreak in a teaching hospital in Beijing, China. Int. J. Infect. Dis. 2014, 23, 105-108. [CrossRef] [PubMed]

120. Seifert, H.; Strate, A.; Schulze, A.; Pulverer, G. Vascular Catheter-Related Bloodstream Infection Due to Acinetobacter johnsonii (Formerly Acinetobacter calcoaceticus var. lwoffii): Report of 13 Cases. Clin. Infect. Dis. 1993, 17, 632-636. [CrossRef] [PubMed]

121. Vijayakrishnan, R.; Rapose, A. Fatal Enterococcus durans aortic valve endocarditis: A case report and review of the literature. Case Rep. 2012, 2012, bcr0220125855. [CrossRef]

122. Falagas, M.E.; Kastoris, A.C.; Vouloumanou, E.K.; Dimopoulos, G. Community-acquired Stenotrophomonas maltophilia infections: A systematic review. Eur. J. Clin. Microbiol. Infect. Dis. 2009, 28, 719-730. [CrossRef]

123. Sakhnini, E.; Weissmann, A.; Oren, I. Fulminant Stenotrophomonas maltophilia Soft Tissue Infection in Immunocompromised Patients: An Outbreak Transmitted via Tap Water. Am. J. Med. Sci. 2002, 323, 269-272. [CrossRef]

124. Turenne, C.; Chedore, P.; Wolfe, J.; Jamieson, F.; Broukhanski, G.; May, K.; Kabani, A. Mycobacterium lacus sp. nov., a novel slowly growing, non-chromogenic clinical isolate. Int. J. Syst. Evol. Microbiol. 2002, 52, 2135-2140. [CrossRef]

125. Kanderi, T.; Shrimanker, I.; Mansoora, Q.; Shah, K.; Yumen, A.; Komanduri, S. Stenotrophomonas maltophilia: An Emerging Pathogen of the Respiratory Tract. Am. J. Case Rep. 2020, 21, e921466-1. [CrossRef]

126. Mauger, T.F.; Kuennen, R.A.; Smith, R.H.; Sawyer, W. Acanthamoeba and Stenotrophomonas maltophilia keratitis with fungal keratitis in the contralateral eye. Clin. Ophthalmol. 2010, 4, 1207-1209. [CrossRef] [PubMed]

127. Prashanth, K.; Ranga, M.P.M.; Rao, V.A.; Kanungo, R. Corneal perforation due to Acinetobacter junii: A case report. Diagn. Microbiol. Infect. Dis. 2000, 37, 215-217. [CrossRef]

128. Pandey, P.K.; Kass, P.H.; Soupir, M.L.; Biswas, S.; Singh, V.P. Contamination of water resources by pathogenic bacteria. $A M B$ Express 2014, 4, 1-16. [CrossRef] [PubMed]

129. Yau, V.; Wade, T.J.; De Wilde, C.K.; Colford, J.M. Skin-related symptoms following exposure to recreational water: A systematic review and meta-analysis. Water Qual. Expo. Health 2009, 1, 79-103. [CrossRef]

130. Pitart, C.; Solé, M.; Roca, I.; Román, A.; Moreno, A.; Vila, J.; Marco, F. Molecular Characterization of blaNDM-5 Carried on an IncFII Plasmid in an Escherichia coli Isolate from a Nontraveler Patient in Spain. Antimicrob. Agents Chemother. 2015, 59, 659-662. [CrossRef]

131. Islam, M.A.; Islam, M.; Hasan, R.; Hossain, M.I.; Nabi, A.; Rahman, M.; Goessens, W.H.F.; Endtz, H.P.; Boehm, A.B.; Faruque, S.M. Environmental Spread of New Delhi Metallo- $\beta$-Lactamase-1-Producing Multidrug-Resistant Bacteria in Dhaka, Bangladesh. Appl. Environ. Microbiol. 2017, 83, e00793-17. [CrossRef] [PubMed]

132. Sugawara, Y.; Akeda, Y.; Hagiya, H.; Sakamoto, N.; Takeuchi, D.; Shanmugakani, R.K.; Motooka, D.; Nishi, I.; Zin, K.N.; Aye, M.M.; et al. Spreading Patterns of NDM-Producing Enterobacteriaceae in Clinical and Environmental Settings in Yangon, Myanmar. Antimicrob. Agents Chemother. 2019, 63, e01924-18. [CrossRef]

133. Berglund, F.; Marathe, N.P.; Österlund, T.; Bengtsson-Palme, J.; Kotsakis, S.; Flach, C.-F.; Larsson, D.G.J.; Kristiansson, E. Identification of 76 novel B1 metallo- $\beta$-lactamases through large-scale screening of genomic and metagenomic data. Microbiome 2017, 5, 134. [CrossRef] [PubMed]

134. Larsson, D.G.J.; Andremont, A.; Bengtsson-Palme, J.; Brandt, K.K.; de Roda Husman, A.M.; Fagerstedt, P.; Fick, J.; Flach, C.-F.; Gaze, W.H.; Kuroda, M.; et al. Critical knowledge gaps and research needs related to the environmental dimensions of antibiotic resistance. Environ. Int. 2018, 117, 132-138. [CrossRef] 
135. Diene, S.M.; Rolain, J.M. Carbapenemase genes and genetic platforms in Gram-negative bacilli: Enterobacteriaceae, Pseudomonas and Acinetobacter species. Clin. Microbiol. Infect. 2014, 20, 831-838. [CrossRef] [PubMed]

136. Meletis, G. Carbapenem resistance: Overview of the problem and future perspectives. Ther. Adv. Infect. Dis. 2016, 3, 15-21. [CrossRef] [PubMed]

137. Halliday, E.; McLellan, S.L.; Amaral-Zettler, L.A.; Sogin, M.L.; Gast, R.J. Comparison of Bacterial Communities in Sands and Water at Beaches with Bacterial Water Quality Violations. PLoS ONE 2014, 9, e90815. [CrossRef] [PubMed] 